\title{
Honouring the Voices of the Ancestors - A Personal View of the Effect of Māori Language Immersion Education in Aotearoa-New Zealand
}

\begin{abstract}
Many studies have been undertaken which focus on identifying factors which impact on the participation and achievement of Māori students in post compulsory education and factors contributing to Māori success in tertiary education. (Jefferies, R. 1997; Tiakiwai, S.J. 2001; Nikora, L. W., Levy, M., Henry, J., \& Whangapirita, L. 2002; Greenwood, J., \& Te Aika, L. 2009), One of the factors identified as an institutional barrier is a lack of recognition of Māori culture and language. This article discusses the importance of university Māori language students being able to write their assignments, dissertations and theses not only in the Māori language, but in their own tribal dialects. Using a case-study approach of the authors' personal experiences of primary, secondary and tertiary education, the case-study will focus specifically on the place of the authors' tribal identity and dialect in this process. Dialect will be illustrated through samples of work submitted for the authors BA (Hons) dissertation, $\mathrm{MA}$ and $\mathrm{PhD}$. This will also demonstrate the importance of writing in the community language, when conducting research on a topic related to that community, and this will be discussed in terms of reflecting a commitment to the survival of that community language and to increasing the corpus of work being produced in the Māori language.
\end{abstract}


This case-study, adopting a narrative approach, will demonstrate a positive outcome for both a university and a Māori student when a) the university provides the right pathways, policies and processes to empower Māori students to write in their native tongue; and $b$ ) the student has the courage and tenacity to continue writing in the Māori language and in their dialect, as a minority in the institution.

\section{Introduction}

Universities are currently faced with government introducing a policy related to increasing the participation and completion rates of Māori in higher education and Performance Based Research Funding. It is reflected by students writing their theses in the Māori language generating four times the weighting of revenue for their universities on thesis completions. As such, universities should be inspired to have a language policy with processes in place for students who wish to write in Māori. Students on the other hand, particularly from immersion schooling contexts, should be motivated and informed while at their secondary school to recognise that writing in Māori can aid their transition from school to university, especially if they have attained a high level of fluency both orally and aurally in the Māori language.

\section{The politics of the Mãori language}

In 1840 New Zealand's founding document, the Treaty of Waitangi ${ }^{1}$, was signed. By 1979, only 139 years later, the loss

\footnotetext{
${ }^{1}$ The Treaty of Waitangi was established as a partnership between the British Crown and Māori as the Indigenous people of Aotearoa/New Zealand. It was signed on the 6th of February 1840 and has been the focus of controversy ever since. The controversy is centred on the fact that two versions of the Treaty were produced. The Māori text was the version which was signed by both Māori and the Crown. This version was a translated from the English text by a non-Indigenous missionary. However, the translation was flawed and was not a correct interpretation of the English text. It is the English text which has been used by the
} 
of the Māori language was so great that it was predicted that it would suffer language death (Walker 1990, pp. 147-8). The status of the language at that time is directly attributed to colonisation and the State policy of assimilation.

Bell states:

Languages die because they are no longer spoken. This happens because their speakers die out without passing them on to the next generation. Only rarely is this because of the extinction of an entire society or race. Usually it happens because from generation to generation (it takes only three or four) the speakers shift to another language. Languages do not die natural deaths. They do not fade away without outside influence. Languages are killed by other languages (Bell 1991, p. 67).

In 1900, over ninety per cent of Māori children started school with Māori as their first language. By 1960 this had fallen to twenty-five per cent (Ka'ai-Oldman 1988, p. 24). As stated, by 1979, the loss of the Māori language was so great that it was expected to die out (Walker 1990, pp. 147-8). In 1984, the number of children entering primary school with Māori as their first language was probably less than two per cent (Ka'ai-Oldman 1988, p. 24). If the language is to survive, it is critical that educators recognise the role language plays as one of the most powerful transmitters of culture. It is crucial to the survival of a cultural community (Darder 1991, p.37).

In Aotearoa/New Zealand, the English language is dominant. This is evidenced in the fact that New Zealand is among the most monolingual countries in the world. It is estimated that ninety to ninety-five per cent of New Zealanders

Crown as the definitive version. Historically, this has been the cause of much contention between Māori and non-Māori. 
can not speak any other language apart from English. This percentage is a lot greater than other primarily English speaking nations such as Britain, the United States of America, Canada, and Australia (Bell 1991, p. 66).

\section{Māori Renaissance}

By the 1960s, it was clear that the State education system had failed many Māori, despite the shift to English. Furthermore, the education system was contributing to the death of the Māori language. After many years of being affected by colonisation, assimilation and language domination, and with no indication of positive action by the State, Māori decided to start reversing the cycle of language decline within their communities by immersing their children in a Māori-speaking environment. The establishment of immersion education was one of many initiatives focusing on Māori language revitalisation.

The idea of Māori immersion pre-schools, otherwise known as Te Kōhanga Reo, or language nests, was first discussed at a national meeting in 1981 (Ka'ai-Oldman 1988, p.27). The Māori language immersion movement was a result of Māori communities working with the Māori Affairs Department to arrest the rapid decline in the health of the Māori language. The motto of Te Kōhanga Reo reflects the urgency of the movement:

Me korero Maori i nga wa katoa, inga wahi katoa Speak Maori at all times and in all places (Jenkins 1994, p.163)

The first Kōhanga Reo was established in April 1982 (Jenkins 1994, p.167). The aim was to have every child who was enrolled in Te Kōhanga Reo bilingual by the age of five. The daily operation of Te Kōhanga Reo was by native speakers of the Māori language, most of whom were elderly (Walker 1990, p.238). 
The cost of the immersion movement fell on parents, families and communities. However, despite this cost, the Te Kōhanga Reo movement experienced rapid growth. In November 1983, there were 188 Te Kōhanga Reo throughout the country (Walker 1990, p.239). By June 1990, there were 609 (Jenkins 1994, p.168). Te Kohanga Reo catered specifically to the needs of Māori children by delivering a curriculum established by Māori parents and Māori educational professionals for Māori children. According to Ka'ai-Oldman, "Te Kōhanga Reo is one of the most dynamic and innovative educational programmes in the country" (1988, p.27).

Following the success of Te Kōhanga Reo, Māori parents became concerned about where to send their school-age children. At the time, there were only twelve bilingual schools throughout the country that offered some instruction in the Māori language. Māori parents were also concerned about sending their children to state schools, as the success of the Te Kōhanga Reo movement was attributed to community control (Walker 1990, p.239).

These concerns were raised at the Māori Educational Development Conference in 1984 (Walker 1990, p.239). Along with parents and community leaders, 300 Māori language teachers attended the conference. These teachers expressed their belief that the State education system was "inherently flawed" and that it was actually "manufacturing Maori failure" (Walker 1990, p.242). The decision was made to develop a school system consistent with the Te Kōhanga Reo philosophy of language revival, recovery and maintenance. Te Kura Kaupapa Māori (primary school) and Te Wharekura (high school) have evolved from the principles of Te Kōhanga Reo. The first Kura Kaupapa Māori was established at Hoani Waititi Marae in 1985 (Jenkins 1994, p.172). It was set up in order to "...find placements for the emerging 'graduates' from $\mathrm{Te}$ Kōhanga Reo, the first of whom had tried State schools and soon found the programmes alienating" (Jenkins 1994, p.172). 
Communities across the country also seized the opportunity to influence schools and teachers to teach their children in their own Māori dialect. The emphasis on dialect has been gaining momentum. As Māori are becoming more comfortable with the quantity of language being taught and spoken, the focus is now on the quality of that language - and maintaining the diversity of dialects is a big part of that.

\section{Case-study using a narrative approach}

I am a descendant of the Waikato tribe, which belongs to the Tainui confederation of tribes, one of the biggest confederations of Māori peoples. I was born and raised in a small Māori community, called Ngāruawāhia, on the banks of the Waikato river, after which my tribe is named. My first language is Māori. I have been fortunate to have lived in a community most of my life where people spoke my native dialect, which is grammatically the same as other Māori dialects, but somewhat different in spelling and pronunciation. My first pre-school year was spent in a Kōhanga Reo, an immersion Māori language pre-school. I then attended kindergarten for the rest of my pre-school education. This was the only time I would be taught in English. When I enrolled in primary school' , I was placed in a Māori language immersion class at my local school which, at that time, had just established a bilingual class. The medium for instruction for the rest of the school was English. In 1994 at age 11, I changed schools moving to Te Wharekura o Rākaumangamanga, a Māori language immersion school. This school consisted of a full primary, intermediate ${ }^{3}$ and a high school, which meant instead of being forced to join a mainstream State high school, I could continue learning in the Māori language. It was at Rākaumanga that my interest in the

\footnotetext{
${ }^{2}$ Primary school is the equivalent to elementary school in the United States.

${ }^{3}$ Intermediate school can be described as a school which is a bridge between primary school and high school. Usually children are aged between 11-13.
} 
Māori language was fostered, and the use of the tribal dialect became a priority. Our community specific language dialect was manifested through compositions and songs, which were frequently performed, thus ensuring its survival amongst the emerging generations. In my senior year, with the help of one of our teachers, my class mates and I established a class that focussed specifically on the teaching of the history, culture and language of the Waikato tribe. We were fortunate that the teacher who helped us, had been raised by his grandfather, who was a well known expert of Waikato knowledge, including tribal customs, lore and language, which he had passed down to our teacher. The fact that I attended a small community school meant that we were aware of this particular teacher's knowledge. Therefore, we approached him and he agreed to put his time into talking with us and teaching us about language and culture. The class was held in our prefects' common room during our free period in the student schedule. This class influenced the way I approach Māori language.

In 2000, I started my first year of university at Otago University in Dunedin, New Zealand, and I quickly realised that my time in tertiary education would be the greatest challenge to my own personal language and dialect preservation. Whilst I was fortunate enough to be raised in my native tongue, many Māori were not. Personally, I have always felt strongly about maintaining my own dialect, even if this has meant more time and energy put into educating those around me. Being a product of Māori immersion schooling has given me the confidence to continue using my native language and dialect throughout my tertiary studies.

When I first started as an undergraduate student at New Zealand's oldest university, there was no policy in place for assignments and examinations submitted in the Māori language despite the fact that the Māori language has been an official language of New Zealand since 1987. However, after a bumpy start, and with the encouragement of my language Professors, I submitted all of my assignments in the Māori 
language. Further to this, I wrote these assignments in my own dialect.

At the time I first embarked on post-graduate study, the university language policy in place at the time required students who elected to write their PhD thesis in Māori, to also write a second thesis in the form of an English translation thus putting the student at a huge disadvantage in terms of the amount of work this involves. Furthermore, such a policy becomes a disincentive for Māori to write their theses in the Māori language. Fortunately, this policy was dramatically revised before I reached $\mathrm{PhD}$ level, largely through the efforts of my language Professors.

My post-graduate study has been my chance to further the use of Māori language within the western academy. At this time, it is also worth noting that my entire post-graduate research has been about my tribal histories and so it has been important for me to use my tribal dialect as the medium for writing about these histories. As Thiong'o states 'Memory resides in language and is clarified by language' (2009, p.113).

Before getting into the specifics of writing my dissertation and theses, it is important to note that differences exist between my own dialect and 'standardised' Māori, that is, the general language that is taught in schools and universities. The most obvious is the use of the word etahi which is used to mean in English the words 'some' or 'other', and it is seen here in its most common form of spelling and pronunciation. A quick and simple example of its use is when saying 'some food,' which in Māori would be ètahi kai, kai being the Māori word for food. For the majority of tribes found in the western region of the North Island of New Zealand, which includes Waikato, this word changes to êtehi. An even older variation of the word êtehi, which has been revived in the new generation of Waikato speakers, is ngetehi. The use of the $n g$ sound in plural definitives, and possessives, in the past, was only heard amongst tribal elders, but now with the importance of heritage language becoming a priority; it has filtered into the new 
generations. The following is a table outlining some of the Waikato dialectal variations on standard particles.

\begin{tabular}{|c|c|c|c|}
\hline $\begin{array}{c}\text { English words } \\
\begin{array}{c}\text { Some/other } \\
\text { (plural) }\end{array}\end{array}$ & standard & $\begin{array}{c}\text { Waikato } \\
\text { Variation 1 }\end{array}$ & $\begin{array}{c}\text { Waikato } \\
\text { Variation 2 }\end{array}$ \\
\hline a/an & tētahi & ètehi & ngētehi \\
\hline this & tēnehi & tēneki & $\mathrm{n} / \mathrm{a}$ \\
\hline these & ēnei & ngēnei & $\mathrm{n} / \mathrm{a}$ \\
\hline those (far) & ērā & ngērā & $\mathrm{n} / \mathrm{a}$ \\
\hline those (near) & ēnā & ngēnā & $\mathrm{n} / \mathrm{a}$ \\
\hline
\end{tabular}

This table highlights the Waikato dialect that I have used throughout my education.

\section{BA Hons dissertation}

My honours dissertation was the first opportunity I had to use my tribal language in a large piece of written work and at a new level of academic study. My main achievement using my tribal language was the use of a language concept known as tongi. There is no one English word that this translates to, but tongi is specific to the Waikato area in that it is associated with a person. Tongi are essentially sayings within my tribe. They are sayings belonging to the second Māori king, King Tāwhiao. Some of these sayings have been deemed prophetic in nature. In my dissertation, I used some of these sayings as they matched perfectly with the some of the themes and subjects I was covering. In using tongi, I not only helped archive heritage language concepts, but I was also able to structure the subject matter of my dissertation in a culturally sound framework. 


\section{Example 1:}

"Ka whakatüria e au tēnei taonga hei āwhina i te pouaru, $i$ te pani me te rawakore. He kūaha whānui kua puare ki te puna tangata me te puna kai." - I establish this gift to care for the orphaned, the widowed and the poor. Let it be a door forever open to the multitude of people, and to a source of food.

This tongi belonging to King Tāwhiao, was a declaration to the people of his intention to support the orphaned, the widowed and the poor. This period began not long after the end of the land confiscations, and King Tāwhiao had returned to his tribal lands from exile, and on seeing how impoverished his people had become, established what is called poukai. These are annual gatherings held at designated villages of the tribe, to help feed and care for the people. These gatherings are also a time to mourn the dead from the passing year, as well as a chance for the people to bring any issues before their King.

\section{MA thesis}

My Master of Arts thesis focussed on the cultural concept of raupatu, or traditional land confiscation. This was contrasted with the confiscation of 1.3 million acres of Waikato land in 1863 by the Crown. My thesis followed a similar framework as my dissertation in terms of using another language concept to frame my work. Whakatauki and whakataua $k \bar{k}$ are sayings that are similar to tongi, but they are not specific to any one person and are also found in all other Māori tribes. In English, these are closely translated as proverbial sayings. However, I only used proverbs that originated from within the Waikato tribe or were specific to Waikato. Using these proverbs reflected the subject matter of each chapter. Furthermore, the proverbial sayings also 
encompassed the subject of land confiscation as a whole, as all of the proverbs that were used came from the time of the confiscations or were about the actual land confiscations. For example:

\section{Example 1.}

'Ko Ngāruawāhia tōku tūrangawaewae.' Ngāruawāhia is my footstool.

This is part of a bigger saying by the second Māori king, King Tāwhiao. This saying marks the territory of Ngāruawāhia (which is a small town in the Waikato tribal area), as the foundation and heart of the Māori King Movement, encapsulated by the word 'tūrangawaewae'. Therefore, I used this saying to head the chapter that laid the foundation of my thesis.

\section{Example 2.}

'Waikato taniwha rau' - Waikato of a hundred creatures.

This saying makes reference to the Waikato River itself, and is used to acknowledge a person who comes from Waikato. Further discussion about the rest of this saying will follow later in the paper. In my thesis I used this saying for the chapter that discussed the actual tribe.

\section{PhD thesis}

My thesis examined the connection between Māori and their environment as the source of identity, with a specific focus on the Waikato tribe and their river. This topic included all three facets of Waikato identity, and also gave me the chance to showcase a heritage language model that connects these identity markers using Māori language concepts. 


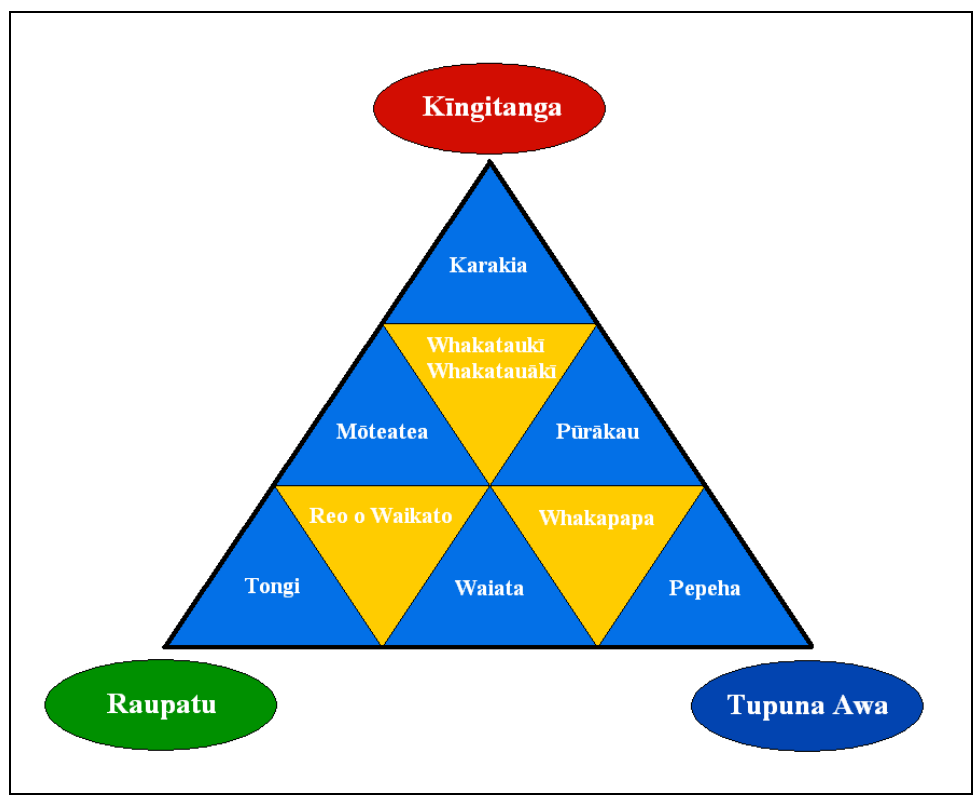

Fig.1. A heritage language model

The collection of triangles in the model, is a traditional wall panel pattern from the Waikato tribe known as niho taniwha, quite literally meaning the 'teeth of the beast'. Taniwha are creatures of nature that have the ability to act as protectors or guardians, but also have the ability to harm. Within the Waikato tribe, taniwha are considered guardians. In fact, because Waikato are a river people, there is a famous saying which declares one's origins from that tribe; he piko, he taniwha, he piko, he taniwha, Waikato taniwha rau, which means, at every bend there is a guardian, Waikato of a hundred guardians. The symbol of the teeth or niho has been used by generations of Waikato people in the arts of weaving and carving. This pattern was used because it represents 
perfectly the location of the research, while also giving meaning to the thesis topic.

The greater triangle has been highlighted to represent the sacred mountain of Taupiri, which is the burial ground for the people of Waikato. Each point of the pyramid are three facets of Waikato identity. The point at the top reflects the Kingitanga symbolising the Māori King Movement. The placement of this at the top of the triangle also represents the location of the burial grounds of the royal family. At the base of the mountain, are raupatu on the left which makes reference to the land confiscations of the Waikato people, and marks the connection of the people to the land. On the right is tupuna awa which makes reference to the Waikato River, which is considered an ancestor of the Waikato people.

These three identity markers are then connected to each other by a group of language concepts that reflect the teeth of the pattern. Each word reflects a different aspect of the Māori language and each has its own place within the heritage language of the Waikato tribe.

\section{Conclusion}

A fear of language 'standardisation' continues to prevail amongst tribes and this fear in some ways has spurred a debate about the importance for the revitalisation of tribal dialects and of heritage languages. It has been the intent of the author, during his post-graduate studies, to produce literature that not only archives his tribal history, but also promotes his tribal dialect. This has meant challenging the university to recognise that it has a responsibility to meet the needs of Māori students who wish to submit work in their own language and dialects with the hope that universities will recognise that there are mutually beneficial rewards in doing so. Most importantly, the research will benefit Māori communities by providing a record of tribal histories and knowledge produced in the Māori language and their dialects. 
There are multiple rewards for the university. First, a mind shift in Māori communities may be realised in that universities will be seen to respect Māori histories, knowledge, language, culture, oral narratives and traditions and thus, have a relevant place within the western academy. This could have the downstream effect of new pathways emerging where Māori communities may be more inclined to channel their children to those universities which produce graduates who have written their theses in the Māori language. Then of course there is the financial reward where universities will reap the four times weighting revenue from Performance Based Research Funding. The importance of this work is summarised by Thiong'o, 'Language is a communication system and carrier of culture by virtue of being simultaneously the means and carrier of memory - what Frantz Fanon calls "bearing the weight of a civilization" (2009, p.20)'.

\section{Bibliography}

Bell, A. 1991. The Politics of English in New Zealand. In G. McGregor \& M. Williams (Eds.), Dirty Silence: Aspects of Language and Literature in New Zealand, (pp. 65-75). University of Waikato Winter Lecture Series of 1990. Auckland: Oxford University Press.

Darder, A. 1991. Culture and Power in the Classroom: A Critical Foundation for Bicultural Education. Westport, Connecticut: Bergin \& Garvey.

Greenwood, J., \& Te Aika, L. (2009). Hei tauira: Teaching and learning for success for Māori in tertiary settings. Wellington, New Zealand: Ako Aotearoa - The National Centre for Tertiary Teaching Excellence.

Jefferies, R. (1997). Mãori participation in tertiary education : Barriers and strategies to overcome them (Prepared for Te Puni Kökiri). Wellington, NZ : Ministry of Māori Development.

Jenkins, K. \& Ka'ai, T. 1994. Maori Education: A Cultural Experience and Dilemma for the State - a New Direction for Maori Society. In E. Coxon, K. Jenkins, J. Marshall \& L. Massey (Eds). The Politics of Learning and Teaching in Aotearoa-New Zealand, (pp. 148-179). Palmerston North: The Dunmore Press Limited. 
Ka'ai-Oldman, T. 1988. A History of New Zealand Education from a Maori Perspective. In Hirsh, W. \& Scott, R. (Eds.), Getting It Right Aspects of Ethnicity and Equity in New Zealand Education, (pp. 2229). Auckland: The Office of Race Relations Conciliator.

Nikora, L. W., Levy, M., Henry, J., \& Whangapirita, L. (2002). Addressing the recruitment and retention of Māori students in tertiary education institutions : A literature review (technical report no. 2), Prepared for the Ministry of Health. Retrieved from Waikato University research commons

http://researchcommons.waikato.ac.nz/bitstream/10289/454/1 Lontent.pdf.

Thiong'o, N. W. 2009. Something Torn and New. An African Renaissance. New York: BasicCivitas Books.

Tiakiwai, S.J. (2001). Māori participation in higher education: Tainui graduates from the University of Waikato 1992-1997.Unpublished PhD thesis, The University of Waikato, Hamilton, New Zealand.

Walker, R. 1990. Ka whawhai tonu mätou - Struggle without end. Auckland: Penguin Books. 